\title{
A Survey on the Role of Fringe Benefits in Employee Satisfaction - An Analysis of Organizations of Pakistan
}

\author{
Sahar Nisar (Corresponding author) \\ Karachi University Business School \\ University of Karachi, Karachi, Pakistan
}

Tel: +92-334-366-3199Ｅ-mail: saharnisar19@gmail.com

Dr. Danish Ahmed Siddiqui

Associate Professor, Karachi University Business School

Karachi University Business School, University of Karachi, Karachi, Pakistan

Tel: +92-333-348-5884_E-mail: daanish79@hotmail.com

Received: Jan. 3, 2019 Accepted: Jan. 28, 2019 Online published: Feb. 10, 2019

doi:10.5296/ijhrs.v9i1.14162 URL: https://doi.org/10.5296/ijhrs.v9i1.14162

\begin{abstract}
This study investigates the relationship between fringe benefits and employee's job satisfaction. More specifically, following variables were taken as fringe benefits (i) Health Protection Benefits, (ii) Recreation Leaves, and (iii) Flexible Working hours. The primary data is gathered through questionnaire from the sample size of 200 respondents based on non-probability convenience sampling technique. The results were later analyzed through exploratory factor analysis and multiple regression. This study showed positive and significant relationship of Recreation Leaves and Health protection benefits on job satisfaction whereas in case of flexible working hours, the relationship seems to be insignificant. Through results, it may be concluded that if a good number of leaves and a good health Protection plan is provided by the employer, the employees tend to be more satisfied and committed towards their job. Whereas, flexible working hours does not much contribute much towards their level of satisfaction towards job. This study might help employers in Pakistan to add commendable benefits programs to their schedule in order to retain their loyal employees and increase firm's productivity.
\end{abstract}

Keywords: fringe benefits, employee satisfaction, flexible working hours 


\section{Introduction}

\subsection{Background}

The practices of human resource management, play an extremely important part in order to achieve organizational goals and in achieving competitive advantage. Human Resource Management practices refer to the activities of organization for managing human resources and assuring that the core reason of employment is to fulfill the organizational objectives. (Schuler and Jackson 1987)

Human Resource practices are being adopted and utilized by most of the companies today in different countries, managers are now believing and understanding the fact that spending more in order to achieve the determined and dedicated employees is not a loss to company but a profit and achievement in the long term. This study examines the role of fringe benefits in employee satisfaction. When it comes to define organization success, employee satisfaction appears weighty. Employee's satisfaction is central concern particularly in the service industry. Need to enhance employee satisfaction is critical because it is a key to business success of any organization. It seems reasonable to believe that understanding of employee role is extremely important as it appears key factor in the success of organization. (Gupta and MANAGEMENT)

The concept of compensations and fringe benefits provided to employees has grown very intensively. Benefits borne by the organization has a positive impact on employee performance and therefore employees work in a positive environment with a relaxed mind.

Fringe benefits refer to the remuneration provided by the employer to the individual employee or a pool of employees as a part of the organizational membership. Fringe benefits are paid to all the employees (unlike incentives which are paid only to the extra ordinary performers) based on their membership in the organization. Fringe benefits are indirect compensation because they are extended as a condition for employment and are not directly related with the performance.(Sharma, Jaiswal et al. 2018) Fringe benefits make the major of company's compensation package. It is expressed that those companies which provides attractive compensation and benefits packages are a way forward from their competitors in the domain of recruiting talented workforce and retaining them in the long run. The prime advantage of the fringe benefits is encouragement and motivation of workers for an increased level of output and the higher coherence.(Steyn 2010)

The main idea of remuneration refers to all kinds of financial and non-financial tangible benefits that employees tend to receive as a part of their employment commitment. There are two major typed of compensation, one are the monetary benefits that are provided in the form of cash against the hours of work done by the employees and the second one refers to the non-monetary benefits which includes non-cash benefits such as medical insurance policy, group life insurance, health benefits, flexible working schedules, leaves, ets. Fringe benefits comprise the employee benefit programs including medical insurance, leaves, flexible working hours, good environment, etc.

Employees prefer working in a firm where they can enjoy the environment, they are 
concerned with the fact that they work in a relaxed way rather than having a harsh work schedule. This fact illustrates the idea that fringe benefits should not, at any cost, be taken for granted by employers. The pay alone does not attract employees to remain in organization, fringe benefits also influences them. (Odunlade 2012)

However, the managers of today's world are reluctant about the fact that the compensation packages can help them achieve the desired level of results effectively. Without straying away from the awareness of the business objectives, the job satisfaction can be mentioned as an essential part of discipline, self-esteem and employee performance. The job satisfaction of the employees' results in increased organizational efficiency and output, decrease in the employee turnover. Moreover, they define salary, reward and compensation as payment which is granted against the services of the employee delivered. Wages or salary is an acknowledgment which is presented as a reward to increase the employee motivation which will lead to improved behavior of workers towards the goals of organization.

\subsection{Reason of Study}

This study aims to understand employees' satisfaction towards the fringe benefits provided to them. To choose such a study topic basically means to strengthen the understanding about the subject matter of "employee benefits", its impact and the different types of fringe benefits that positively impact on employees' job satisfaction. The need to conduct the research is to highlight the barriers and restraints that are faced by the employer when the employees' get de-motivated after a span of time of his employment.

\subsection{Problem Statement}

After recruiting an employee, companies tend to expect maximum employee productivity. The problem arises when the employees, at a certain point start looking for other opportunities. And their job satisfaction starts to shrink due to lack of fringe benefits provided by the employer.

\subsection{Gap Analysis}

Many researches have been made recently on the importance of benefits programs for employees, fringe benefits and employee satisfaction.

(Chukwudumebi and Kifordu 2018) concluded that fringe benefits play a vital role in the level of employees' morale and productivity of companies and there is an association between fringe benefits and welfare matters.

(Sierpińska and Kulisa 2018) analyzed that the most popular benefits are primary and special health care, professional training and courses, gym and fitness club passes, use of business phone for private purposes and life insurance while, the most desirable additional benefits among employees include an extended medical package, a company car for private use and flexible working hours. However, (Sharma, Jaiswal et al. 2018) states that employee security contributes most to the employee satisfaction in comparison with the other types of fringe benefits. (Ali, Hussain Khan et al. 2018) indicated through results that salary has the strongest impact on job satisfaction level and relationship with co-workers has weakest 
impact on it. Opportunities for promotion and recognition \& rewards emerged as major sources of dissatisfaction. The study showed that personal determinants like gender, age, personality, marital status and organizational determinants like salary, promotion opportunities, recognition \& rewards, relationship with supervisor \& co-workers, fringe benefits, working conditions, work itself and tenure have a significant positive relationship with job satisfaction except qualification of employees which has insignificant relationship with it. Opportunities for promotion and recognition \& rewards emerged as major sources of dissatisfaction. In another study, (Raja, Sheikh et al. 2018) tested the hypothesis that employees in Pakistan (i.e., an underdeveloped economy) would be more focused on rewards than procedures. He suggested that workers in an underdeveloped economy like Pakistan may be more concerned with fairness in the distribution of rewards than procedural fairness. Therefore, in such context, procedures may be less likely to reduce negative consequences of unfair reward distribution.

These research studies analyzed the impact of monetary and non-monetary benefits to the level of satisfaction of employees. As fringe benefits include many types of non - monetary benefits as well, it becomes difficult to analyze the impact of non-monetary benefits to the level of satisfaction of employees. A distinct approach has not been adopted by the researches to measure the impact of non-monetary incentives separately.

Through this research, an effort has been made to analyze the impact of different types of non-monetary benefits on the level of employee job satisfaction. On the contrary, this research has been made for the organizations within Pakistan and has analyzed that which type of fringe benefits among the three (recreation leaves, health protection benefits and flexible working hours) appears the most important and should be made the part of employee compensation plan in order to retain the employees in the long - run..

\subsection{Objectives of Research}

1) To determine the impact of fringe benefits on employees' satisfaction.

2) To find out the relationship between different sorts of fringe benefits and employees' satisfaction.

\subsection{Key Research Questions}

1) What role do fringe benefits play in employee job satisfaction?

2) How different types of fringe benefits affect job satisfaction?

\section{Literature Review}

"Fringe Benefit" means any benefit provided or deemed to be provided by reason of an employment or office. The basis for the taxation of fringe benefits is article 4(1)(b) of the Income Tax Act, which applies to all gains or profits derived from an employment or office, regardless of whether they are received in cash or in kind and whether they are received in terms of the normal conditions of the contract of service or by way of a special or ex gratia allowance. Similarly, when a payment or other benefit represents a reward for services 
rendered by a person it is taxable not only when it is provided directly from the employer to the employee but also when it is provided indirectly, that is either by third parties or to third parties.

Although fringe benefits have the nature of normal income they have certain characteristics which warrant special regulation that seeks to:

a) ensure that no doubts are raised as to the taxation of fringe benefits,

b) establish in which circumstances and to what extent are benefits to be treated as fringe benefits,

c) determine their value, and

d) Provide for the manner in which the Final Settlement System is to apply to fringe benefits.

Once fringe benefits are taxable in the same way as normal salaries and wages, an employer who incurs a cost in providing fringe benefits may claim that cost as a deduction from his income to the same extent as he would qualify for a deduction in terms of the normal provisions of the Income Tax Acts had he paid, instead, normal wages.

\subsection{Health Protection Benefits}

According to a survey carried out by Employee Benefit Research Institute (EBRI), Most of the employees are not interested in the combination of the benefits and wages that are being offered by the employer currently, and are pretty much satisfied with the health benefits provided by the company. Furthermore, Fronstin states that for workers, so far the health benefits have been the most important and consistent element in the employee benefits. Employees who are given the health protection benefits seem to be satisfied with it. (Fronstin 2013)

Workplace health promotion has the following extensive benefits:

a) The more healthy workers are, the more productive they become for the firm and thus are the prime strategy.

b) Workplace health promotion reduces absenteeism and increase staff morale.

c) It helps in employee's increased job satisfaction and enhances self-esteem

d) It makes the workplace safe which contribute in a sustainable development.

The health of workforce and the overall productivity of the firm is interwoven and linked together, along with the health of nation's economy, the employers now seem to have realized the fact that the link between a workers' health and firm's performance is inseparable, and in order to have healthier workers, they are improving the health protection benefit programs and activities. The author continues to state that some employee also permit their employees to take a few days off from work without sacrificing their salary. (Kamau 2013) 


\subsection{Recreation Leave}

According to (Naithani 2009) Establishment of set of guidelines and rules by an organization about the processes, time frame, and reporting procedures for the time taken off is called a Leave Policy, in accordance to the governing local labor law. This study focuses on Annual leave, Sick Leave and Maternity Leave.

\subsection{Annual Leave}

Annual leave is the paid time off the working hours or it can be referred as a vacation time. The vacation time or the paid time off is provided to the employees in several circumstances by the employer, some of the common ways are the lunch breaks, rest periods, holidays and vacations. But there are also other purposes due to which the leaves are granted to the employees. Leave policy refers to the number of days which employees accrue for leave annually, and also include the standard procedures in order to request for the leave. Moreover, it involves the implications of the days of leaves unused. Many writers have acquired and addressed to the strong relationship between the utilization of annual leaves and the employee's overall productivity. (Naithani 2009)

Most of the organizations allow the annual leave for 21 to 30 days; however, some of the firms on discretion tend to offer extra leave days than what is prescribed in labor law. According to a study on employee productivity, they concluded that the level of employee performance and the well-executed employee work life balance are closely interwoven. Furthermore, authors affirm that annual leave has several benefits in work life. Low level of employee anxiety and stress, low level of employee burnout, and employee mental refreshment can be counted as some of those benefits. (Sirma 2015)

\subsection{Sick Leave}

Another work life balance opportunity for the employees is Sick Leave. It is most probable that work pressure can create anxiety; stress and related ailment can make an employee sick. Employees surrender in front of the natural sickness or work-related maladies. Consequently, they are not able to focus and concentrate on work because of the discomfort that comes from the ailment. Most often than not, the sickness in the employees' body make them forbear to give the required energy, attention and mental focus in performing the optimal task. In the research done by (King, Karuntzos et al. 2012), the findings suggest that the employees who are given sick leave facility by the employers tend to recover faster from illness as compared to those employers who insist on employees' presence at work regardless of maladies. However, (Casper, Harris et al. 2011) states that the employers who offer paid sick are more likely to have a performance edge over those firms or competitors who are reluctant to the idea of providing paid sick leaves. And employees who know that they will not get any compensation or benefit if they asked for a sick leave, never actually ask for it. Consequently, the employees work with lack of optimal concentration on work because of the mental and physical imbalanced health. Quality of life can be characterized on the basis of the physical and mental fitness. The positive and encouraging working environment that intensify the quality of like also have an positive impact on job satisfaction, team work and 
employee performance. Focused, synergized and ultimate employee work performance has been witnessed in the organizations which do make provisions for employee wellness through benefits and facilities like sick leave. (Sirma 2015)

\subsection{Maternity Leave}

According to the Maternity Benefit Ordinance, 1958, after qualifying the period of four months of employment, a female worker is allowed to be given up to six weeks prenatal and postnatal leave, and during that leave, the female worker/employee is supposed to be provided the salary drawn on what she has been earning from the previous month. The ordinance is relevant for all the industrial and commercial establishments who hire female employees. Furthermore, the termination of a woman employee, during the time period of her maternity leave is also restricted. Likewise, the Mines Maternity Benefits Act, 1941, is applicable for all the mines in which female employees are appointed.

(King, Karuntzos et al. 2012) States that in Maternity Leave, the expectant woman employee need some time off for the delivery of the baby or for nursing of an infant after the child is born. In a study of Parents' transition back to the paid work after the birth of a child, (Jansen, Mohren et al. 2010) observed that female employees who do not have any access or little access to paid parental leave were most of the times distracted at work and they reported decreased performance due to conflicts of work as well as parenting. As employees grow older; they value the remuneration packages which can serve their family like maternity benefits, children benefits, paid vacations etc.

\subsection{Flexible Working Hours}

Many organizations consider the flexible working hours as a vital benefit provided to the employees. However, the description about the circumstances and extent of flexibility of the hours is not explained in detail in their official websites. Flexible working hours is the most used non-monetary incentive, as found in a study conducted on the employees of T.C Ministry of Culture and Tourism Establishment. The variation in job's time and place which allows the worker to accomplish their work related duties without harsh adherence to the standard working hours is known as flexible working arrangement. Flexible working arrangements include the flexibility of scheduling, location, and length of the work that employees have at their disposal. Past researches done on flexible working arrangements have observed a positive impact on the job satisfaction and working schedule.

Having an increased access to flexible working hour can not only be beneficial for the employees with family responsibilities, but for all the working employees. Since the job satisfaction is inversely proportional to the number of job quits, this can be a beneficial compensation for both, the employees and the employer.(Jansen, Mohren et al. 2010) 


\subsection{Theoretical Framework}

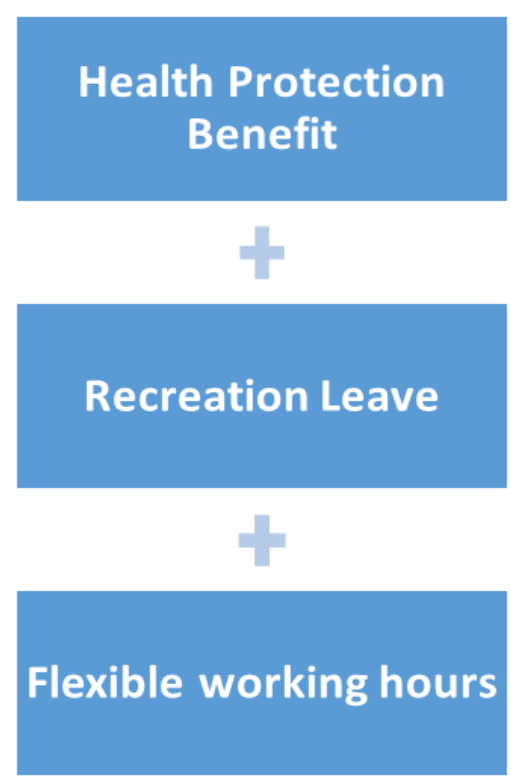

Independent Variables

\section{EMPLOYEE JOB SATISTAFTION}

\subsection{Hypothesis}

\subsubsection{Health Protection Benefit}

H0: Health protection benefits might not have an impact on an employee's job satisfaction.

H1: Health protection benefits might have an impact on an employee's job satisfaction.

\subsubsection{Recreation Leaves}

H0: Recreation leaves shall not play a role in shifting of employee's job satisfaction.

H2: Recreational leaves shall play a role shifting of employee's job satisfaction.

\subsubsection{Flexible Working Hours}

H0: Flexible working hours may not affect an employee's job satisfaction.

H3: Flexible working hours may affect an employee's job satisfaction.

\section{Research Methodology}

This research has used primary information and data from survey research to know about diverse variables of study. Primary data has been extracted through Questionnaires filled from the employees of organizations inside Karachi. This population has been identified and set as a sample of the total population i,e 200 employees. In this survey, we chose 200 respondents as the sample size by asking them that whether they observe a relationship between fringe benefits and employee satisfaction. The data gathered was tested for Hypothesis with the help of SPSS software used as a Statistical Tool to reach some concrete 


\section{Macrothink}

International Journal of Human Resource Studies

ISSN 2162-3058 2019, Vol. 9, No. 1

conclusion. The survey collected the essential information and recorded individual's responses for the examination.

All the questions were designed in likert scale (1=Strongly Agree 2=Agree, 3=Neutral, 4= Disagree, 5=Strongly Disagree). All the questions regarding to each variables are given below.

\subsection{Data Analysis}

The data collected for the research is quantitative whereas attitudinal skill "Likert skill" is also used to extract information about the research problem from the selected sample. The sample was selected on the basis of suitability for this study. Due to time and resources constraints, most of the questionnaires were distributed through google forms and by distribution of questionnaires in different companies within Karachi.

\subsection{Demographics}

The frequencies for the demographic data obtained from this survey are given below:

\begin{tabular}{l|l|l}
\hline & Frequency & Percent \\
\hline Male & 90 & 45.0 \\
\hline Female & 110 & 55.0 \\
\hline Total & 200 & 100.0 \\
\hline \multicolumn{3}{c}{ Gender }
\end{tabular}

Table above shows that most of the participants in this survey are females consisting $55 \%$ of the total population.

\begin{tabular}{l|l|l}
\hline & Frequency & Percent \\
\hline 21 to 30 years & 118 & 59.0 \\
31 to 40 years & 56 & 28.0 \\
41 to 50 years & 18 & 9.0 \\
Below 20 years 8 & 4.0 \\
Total & 200 & 100.0 \\
\hline \multicolumn{2}{l|}{ Age Group }
\end{tabular}

Table above illustrates that the population in this survey belongs to various age groups. But the majority lies in the age bracket of 21 to 30 years.

\begin{tabular}{l|l|l}
\hline & Frequency & Percent \\
\hline $10,000-25,000$ & 47 & 23.5 \\
\hline $25,000-50,000$ & 36 & 18.0 \\
\hline $50,000-100,000$ & 85 & 42.5 \\
\hline Below 10000 & 25 & 12.5 \\
\hline Student & 7 & 3.5 \\
\hline Total & 200 & 100.0 \\
\hline
\end{tabular}

Income level 


\section{Macrothink}

International Journal of Human Resource Studies

ISSN 2162-3058

2019, Vol. 9, No. 1

Table shows that the respondents taken in the survey are paid different compensation packages.

\begin{tabular}{c|c|c}
\hline & Frequency & Percent \\
\hline Bachelors & 120 & 60.0 \\
\hline Masters & 72 & 36.0 \\
\hline Matriculation & 8 & 4.0 \\
\hline Total & 200 & 100.0 \\
\hline
\end{tabular}

Qualification

Table above demonstrates that the academic level of respondents is majority from bachelors' level of education which is almost 60 percent of the total population.

\subsection{Descriptive Analysis of Responses for Each Question}

\begin{tabular}{|c|c|c|c|c|}
\hline Questions & Mean & Median & Mode & Std. Dev. \\
\hline \multicolumn{5}{|l|}{ Recreation leaves } \\
\hline In the Annual leave, employees get enough time to spend with family & 1.5 & 1.5 & 1 & 0.5013 \\
\hline Because of annual leave, employees feel relaxed and it directly affects their performance & 1.55 & 1.5 & 1 & 0.591 \\
\hline $\begin{array}{l}\text { Employees who get the paid sick leave from the employer tend to be much satisfied } \\
\text { as compared to those who do not get the sick leave. }\end{array}$ & 1.65 & 2 & 1 & 0.6555 \\
\hline Female employees prefer working in a firm where they are provided with Maternity Leaves. & 1.55 & 2 & 2 & 0.4987 \\
\hline $\begin{array}{l}\text { Maternity leave helps female employees focus on work without } \\
\text { getting distracted about home responsibilities }\end{array}$ & 1.55 & 2 & 2 & 0.4987 \\
\hline Parental leave has a positive impact on an employee's job satisfaction. & 1.65 & 2 & 2 & 0.5737 \\
\hline \multicolumn{5}{|l|}{ Health Protection Benefits } \\
\hline Health protection benefits are considered as the most preferred non-monetary incentives & 2.7 & 2 & 2 & 1.4213 \\
\hline I am satisfied with the health benefits that I am provided against my job description. & 1.85 & 2 & 2 & 0.7941 \\
\hline Job satisfaction increases if the employee is granted with a proper health insurance facility. & 2.15 & 2 & 2 & 0.7941 \\
\hline Health protection benefits are important than any other monetary or non-monetary benefits. & 1.55 & 2 & 2 & 0.4987 \\
\hline \multicolumn{5}{|l|}{ Flexible Working Hours } \\
\hline Flexible working arrangements helps employees organize their work in a better way & 1.45 & 1 & 1 & 0.591 \\
\hline $\begin{array}{l}\text { Organizations can observe a positive impact of flexibility of working } \\
\text { condition on an employee's satisfaction of job. }\end{array}$ & 2.1 & 2 & 2 & 0.5399 \\
\hline Flexible working hours helps in retaining potential employees & 2.65 & 3 & 3 & 0.8551 \\
\hline \multicolumn{5}{|l|}{ Employee Job Satisfaction } \\
\hline I would recommend employment at this organization ta a friend. & 1.7 & 2 & 1 & 0.7159 \\
\hline I rarely think about looking for a job at another company. & 2.15 & 2 & 2 & 0.7281 \\
\hline My organization is flexible with respect to my family responsibilities. & 1.65 & 2 & 2 & 0.7281 \\
\hline I feel the current benefits offered to me are sufficient for me and my family. & 2.3 & 2 & 2 & 0.9023 \\
\hline
\end{tabular}




\subsubsection{Recreation Leaves}

Statement \# 01: The figures show that majority of the employees strongly agree on the fact that because of a good number of annual leaves, they get enough time to spend with their families.

Statement \# 02: The findings of this statement show that majority of employees strongly believe that because of annual leaves they feel much relaxed and with this they perform more properly.

Statement \# 03: This statement shows the level of satisfaction of employees because of sick leaves provided to them. The statistics show that majority of employees feel much satisfied because of sick leaves and they would have been dissatisfied if they were not provided sick leaves.

Statement \# 04: This statement shows to what extent are maternity leaves important for married female employees and the statistics show that majority of employees agree with the statement that female employees prefer to work in an organization which understands the need of maternity leaves and provide maternity leaves.

Statement \# 05: The statistics show that majority of employees agree that maternity leaves helps female employees focus on work without getting distracted about their home responsibilities.

Statement \# 06: This statement shows a relationship between employee satisfaction and paternal leaves. The statistics shows a positive impact of paternal leaves on employee job satisfaction.

\subsubsection{Health Protection Benefits}

Statement \# 01: This question tells to how much health protection benefits are important among the non- monetary incentives. The statistics shows that majority of population "agrees" on the above statement and it might be said that health protection benefit is an important factor.

Statement \# 02: This statement that how much an employee is satisfied with health protection plan being provided to him/ her against the job duties and level of work done by him/ her. The statistics shows that majority of employees are satisfied with the health protection plans provided to them by their respective companies.

Statement \# 03: This statement analyses the consent of employees about the importance of a good health insurance plan. The statistics define that majority of employees agrees to the fact that they feel more satisfied if they are provided with a proper health insurance plan.

Statement \# 04: This statement analyses the level of importance of health protection facilities. Majority of the employees agrees on the fact that health protection benefit is the most important benefit than any other monetary and non- monetary benefits. 


\subsubsection{Flexible Working Hours}

Statement \# 01: This statement illustrates the importance of flexible working arrangements towards the level of job performance. The statistics show that majority of employees strongly believe that flexible working arrangements help them work in a much better way.

Statement \# 02: This statement tells the relationship between flexible working hours and employee job satisfaction. Majority of employees agrees that if organizations seek a positive impact of flexibility of working condition on an employee's satisfaction of job.

Statement \# 03: The statistics show that flexible working hours does not help much in retaining potential employees.

\subsubsection{Employee Job Satisfaction}

Statement \# 01: This statement analyses the level of satisfaction of employee towards organization because of benefits provided to them. The statistics show that majority of employees agree with the above statement and would recommend employment in the same organization to a friend.

Statement \# 02: The statistics show that majority of employees agree with the above statement and they rarely think about looking for another job as they are satisfied with their current job.

Statement \# 03: The findings show that majority of employees agrees with the statement that their organization is flexible with respect to their family responsibilities and it shows a moderate positive level of satisfaction.

Statement \# 04: This statement shows the level of satisfaction of employee with respect to the benefits provided to them by the employer. Majority of respondents agree that the current benefits provided to them are sufficient to them and their family.

\subsection{Factor Analysis}

Factor Analysis is usually used data or variable reduction method. This multivariate statistical method is used for three prime motives:

a) Decrease the numeral of variables, from large to small

b) Establish underlying proportions between measured variables and hypotheses

c) Deliver constructs validity indication

Factor analysis is a technique that is used to reduce a large number of variables into fewer numbers of factors. This technique extracts maximum common variance from all variables and puts them into a common score. As an index of all variables, we can use this score for further analysis. Factor analysis is part of general linear model (GLM) and this method also assumes several assumptions: there is linear relationship, there is no multicollinearity, it includes relevant variables into analysis, and there is true correlation between variables and factors. Several methods are available, but principle component analysis is used most 
commonly.

Principal component analysis is the most common method used by researchers. PCA starts extracting the maximum variance and puts them into the first factor. After that, it removes that variance explained by the first factors and then starts extracting maximum variance for the second factor. This process goes to the last factor.

\begin{tabular}{|c|c|c|c|c|c|c|c|c|c|}
\hline \multirow[b]{2}{*}{$\begin{array}{l}\text { Compo } \\
\text { nent }\end{array}$} & \multicolumn{3}{|c|}{ Initial Eigenvalues } & \multicolumn{3}{|c|}{$\begin{array}{l}\text { Extraction Sums of } \\
\text { Squared Loadings }\end{array}$} & \multicolumn{3}{|c|}{$\begin{array}{l}\text { Rotation Sums of Squared } \\
\text { Loadings }\end{array}$} \\
\hline & Total & $\begin{array}{l}\% \text { of } \\
\text { Variance }\end{array}$ & $\begin{array}{l}\text { Cumulati } \\
\text { ve } \%\end{array}$ & Total & $\begin{array}{l}\% \text { of } \\
\text { Variance }\end{array}$ & $\begin{array}{l}\text { Cumulati } \\
\text { ve } \%\end{array}$ & Total & $\begin{array}{l}\% \text { of } \\
\text { Variance }\end{array}$ & $\begin{array}{l}\text { Cumulat } \\
\text { ive } \%\end{array}$ \\
\hline 1 & $\begin{array}{l}5.75 \\
9\end{array}$ & 33.876 & 33.876 & $\begin{array}{l}5.75 \\
9\end{array}$ & 33.876 & 33.876 & $\begin{array}{l}4.97 \\
3\end{array}$ & 29.254 & 29.254 \\
\hline 2 & $\begin{array}{l}3.26 \\
6\end{array}$ & 19.211 & 53.087 & $\begin{array}{l}3.26 \\
6\end{array}$ & 19.211 & 53.087 & $\begin{array}{l}2.93 \\
7\end{array}$ & 17.277 & 46.531 \\
\hline 3 & $\begin{array}{l}1.87 \\
7\end{array}$ & 11.041 & 64.128 & $\begin{array}{l}1.87 \\
7\end{array}$ & 11.041 & 64.128 & $\begin{array}{l}2.29 \\
5\end{array}$ & 13.502 & 60.033 \\
\hline 4 & $\begin{array}{l}1.45 \\
6\end{array}$ & 8.567 & 72.695 & $\begin{array}{l}1.45 \\
6\end{array}$ & 8.567 & 72.695 & $\begin{array}{l}2.15 \\
2\end{array}$ & 12.661 & 72.695 \\
\hline
\end{tabular}

Extraction Method: Principal Component Analysis.

Total Variance Explained

According to the Kaiser Criterion, Eigenvalues is a good criterion for determining a factor. If Eigenvalues is greater than one, we should consider that a factor and if Eigenvalues is less than one, then we should not consider that a factor. According to the variance extraction rule, it should be more than 0.7 . If variance is less than 0.7 , then we should not consider that a factor.

Eigenvalues is also called characteristic roots. Eigenvalues shows variance explained by that particular factor out of the total variance. From the commonality column, we can know how much variance is explained by the first factor out of the total variance. For example, if our first factor explains $68 \%$ variance out of the total, this means that $32 \%$ variance will be explained by the other factor.

\begin{tabular}{l|l|l}
\hline $\begin{array}{l}\text { Health protection benefits are considered as the most preferred } \\
\text { non-monetary incentives }\end{array}$ & 1.000 & .827 \\
\hline $\begin{array}{l}\text { I am satisfied with the health benefits that I am provided against my job } \\
\text { description. }\end{array}$ & 1.000 & .719 \\
$\begin{array}{l}\text { Job satisfaction increases if the employee is granted with a proper health } \\
\text { insurance facility. }\end{array}$ & 1.000 & .648 \\
\hline $\begin{array}{l}\text { Health protection benefits are important than any other monetary or } \\
\text { non-monetary benefits. }\end{array}$ & 1.000 & .925 \\
\hline \begin{tabular}{l} 
In the Annual leave, employees get enough time to spend with family \\
\hline
\end{tabular} & 1.000 & .777 \\
\hline
\end{tabular}




\begin{tabular}{l|l|l}
\hline $\begin{array}{l}\text { Because of annual leave, employees feel relaxed and it directly affects } \\
\text { their performance }\end{array}$ & 1.000 & .882 \\
\hline $\begin{array}{l}\text { Employees who get the paid sick leave from the employer tend to be } \\
\text { much satisfied as compared to those who do not get the sick leave. }\end{array}$ & 1.000 & .791 \\
\hline $\begin{array}{l}\text { Female employees prefer working in a firm where they are provided with } \\
\text { Maternity Leaves. }\end{array}$ & 1.000 & .686 \\
\hline $\begin{array}{l}\text { Maternity leave helps female employees focus on work without getting } \\
\text { distracted about home responsibilities }\end{array}$ & 1.000 & .925 \\
\hline $\begin{array}{l}\text { Parental leave has a positive impact on an employee's job satisfaction. } \\
\text { Flexible working arrangements helps employees organize their work in a } \\
\text { better way }\end{array}$ & 1.000 & .759 \\
\hline $\begin{array}{l}\text { Organizations can observe a positive impact of flexibility of working } \\
\text { condition on an employee's satisfaction of job. }\end{array}$ & 1.000 & .817 \\
\hline $\begin{array}{l}\text { Flexible working hours helps in retaining potential employees } \\
\text { I would recommend employment at this organization ta a friend. }\end{array}$ & 1.000 & .757 \\
\hline \begin{tabular}{l} 
I rarely think about looking for a job at another company. \\
\hline My organization is flexible with respect to my family responsibilities.
\end{tabular} & 1.000 & .786 \\
\hline $\begin{array}{l}\text { I feel the current benefits offered to me are sufficient for me and my } \\
\text { family. }\end{array}$ & 1.000 & .426 \\
\hline
\end{tabular}

Extraction Method: Principal Component Analysis.

Communalities

The table of communalities displays the level of variance (i.e the factors having communality value more that 0.5 will be considered for further analysis. Else these variables are to be removed from further steps of factor analysis) in the variables has been accounted for by the extracted factors. In this table it is illustrated that all the factors have cumulative value more than 0.5 and will be considered for further steps of factor analysis.

\begin{tabular}{l|l|l|l|l}
\hline & \multicolumn{3}{l}{ Component } \\
\cline { 2 - 5 } & 1 & 2 & 3 & 4 \\
\hline $\begin{array}{l}\text { In the Annual leave , } \\
\text { employees get enough } \\
\text { time to spend with }\end{array}$ & 0.854 & -0.037 & 0.191 & -0.096 \\
family & & & & \\
\hline $\begin{array}{l}\text { Because of annual leave, } \\
\text { employees feel relaxed } \\
\text { and it directly affects } \\
\text { their performance }\end{array}$ & & & & \\
\end{tabular}


Employees who get the paid sick leave from the employer tend to be much satisfied as compared to those who do not get the sick leave.

\begin{tabular}{|c|c|c|c|c|}
\hline $\begin{array}{l}\text { Female employees prefer } \\
\text { working in a firm where } \\
\text { they are provided with } \\
\text { Maternity Leaves. }\end{array}$ & 0.804 & -0.075 & -0.176 & -0.06 \\
\hline $\begin{array}{l}\text { Maternity leave helps } \\
\text { female employees focus } \\
\text { on work without getting } \\
\text { distracted about home } \\
\text { responsibilities }\end{array}$ & 0.746 & 0.502 & -0.27 & 0.209 \\
\hline $\begin{array}{ll}\text { Parental leave } & \text { has a } \\
\text { positive impact } & \text { on an } \\
\text { employee's } & \text { job } \\
\text { satisfaction. } & \end{array}$ & 0.709 & 0.461 & -0.129 & 0.164 \\
\hline $\begin{array}{l}\text { I would recommend } \\
\text { employment at this } \\
\text { organization ta a friend. }\end{array}$ & 0.093 & 0.781 & 0.259 & 0.424 \\
\hline $\begin{array}{l}\text { I rarely think about } \\
\text { looking for a job at } \\
\text { another company. }\end{array}$ & 0.369 & 0.655 & 0.199 & 0.119 \\
\hline $\begin{array}{l}\text { My organization is } \\
\text { flexible with respect to } \\
\text { my family } \\
\text { responsibilities. }\end{array}$ & 0.008 & 0.879 & 0.115 & 0.024 \\
\hline $\begin{array}{l}\text { I feel the current benefits } \\
\text { offered to me are } \\
\text { sufficient for me and my } \\
\text { family. }\end{array}$ & -0.13 & 0.546 & -0.148 & -0.301 \\
\hline $\begin{array}{l}\text { Health } \\
\text { benefits are considered } \\
\text { as the most preferred } \\
\text { non-monetary incentives }\end{array}$ & -0.16 & -0.05 & 0.89 & 0.081 \\
\hline $\begin{array}{l}\text { I am satisfied with the } \\
\text { health benefits that I am } \\
\text { provided against my job } \\
\text { description. }\end{array}$ & 0.001 & 0.197 & 0.824 & 0.033 \\
\hline $\begin{array}{l}\text { Job satisfaction increases } \\
\text { if the employee is } \\
\text { granted with a proper } \\
\text { health insurance facility. }\end{array}$ & 0.066 & -0.176 & 0.124 & -0.773 \\
\hline
\end{tabular}




\begin{tabular}{l|l|l|l|l}
$\begin{array}{l}\text { Flexible } \\
\text { arrangements working } \\
\text { employees organize their } \\
\text { work in a better way }\end{array}$ & 0.136 & -0.089 & 0.249 & 0.854 \\
\hline $\begin{array}{l}\text { Flexible working hours } \\
\text { helps in retaining } \\
\text { potential employees }\end{array}$ & -0.21 & 0.134 & 0.575 & 0.603 \\
\hline
\end{tabular}

Extraction Method: Principal Component Analysis.

Rotation Method: Varimax with Kaiser Normalization.

Rotated Component Matrix

The idea of rotation is to reduce the number factors on which the variables under investigation have high loadings. Rotation does not actually change anything but make the interpretation of the analysis easier. The table above shows that responses of the questions for recreation leaves are loaded on factor 1 while employee satisfaction responses is loaded on factor 2. Health protection benefits is loaded on factor 3 and flexible working hours is loaded on factor 4.

There were two questions that were deleted from the factor matrix due to single factor loading. The six questions significantly loaded on recreation leaves. The next four factors were significantly loaded on employee satisfaction. Furthermore, three factors were significantly loaded on health protection flexible working hours.

\subsection{Regression Analysis}

\begin{tabular}{|c|c|c|c|c|c|c|}
\hline & & \multicolumn{2}{|c|}{$\begin{array}{c}\text { Unstandardized } \\
\text { Coefficients }\end{array}$} & \multirow{2}{*}{$\begin{array}{c}\text { Standardized } \\
\text { Coefficients }\end{array}$} & \multirow[b]{2}{*}{$\mathrm{t}$} & \multirow[b]{2}{*}{ Sig. } \\
\hline \multicolumn{2}{|c|}{ Model } & B & Std. Error & & & \\
\hline \multirow[t]{4}{*}{1} & (Constant) & $3.331 \mathrm{E}-17$ & .071 & & .000 & 1.000 \\
\hline & HPB & .000 & .071 & .000 & .000 & 1.000 \\
\hline & RL & .000 & .071 & .000 & .000 & 1.000 \\
\hline & FWH & .000 & .071 & .000 & .000 & 1.000 \\
\hline
\end{tabular}

a. Dependent Variable: EMP_SAT

\section{Coefficients}

The table shows the impact of the independent variables (health protection benefits, recreation leaves, flexible working hours) on dependent variable (employee satisfaction). The impact of these variables is given below.

\subsubsection{Recreation Leaves}

H1. Recreational leaves shall play a role shifting of employee's job satisfaction.

The table above shows that value of significance for the variable recreation leaves is 0.000 
which is lesser than alpha. However result is significant and hence the alternative hypotheses is rejected. So we can say that Recreation leaves have positive impact on employee satisfaction.

\subsubsection{Health Protection Benefits}

H2. Health protection benefits might have an impact on an employee's job satisfaction.

The value of Health protection benefits is 0.00 therefore the results are significant and alternative hypothesis is rejected. So from the regression results it can be concluded that health protection benefits have an impact on employee satisfaction.

\subsubsection{Flexible Working Hours}

H3. Flexible working hours may affect an employee's job satisfaction.

The regression results also show significant impact of flexible working on employee satisfaction. So flexible working hours has a slight positive impact on employee satisfaction.

\begin{tabular}{|c|c|c|c|c|c|c|}
\hline \multicolumn{7}{|c|}{ ANOVA } \\
\hline Model & & $\begin{array}{l}\text { Sum } \\
\text { Squares }\end{array}$ & df & Mean Square & $\mathrm{F}$ & Sig. \\
\hline \multirow[t]{3}{*}{1} & Regression & .000 & 3 & .000 & .000 & $1.000 \mathrm{~b}$ \\
\hline & Residual & 199.000 & 196 & 1.015 & & \\
\hline & Total & 199.000 & 199 & & & \\
\hline
\end{tabular}

a. Dependent Variable: EMP_SAT

b. Predictors: (Constant), FWH, RL, HPB

It is found that the utilized model in the analysis is appropriate since the needed esteem value confirms that the research has been conducted on substantial grounds.

\subsection{Discussion}

Many researches have been done on national and international level on the importance of benefits programs, fringe benefits and how to increase the satisfaction level of employees in order to retain talented workforce and to increase the contribution of human resource towards firms' productivity. But a distinct approach has been adopted has been adopted in this study as compared to the previous researched made. This research study focuses on the different types of non-monetary fringe benefits and a comparison between them. It focuses on which type of fringe benefit contributes mostly towards the satisfaction of employees. On the contrary, this research has been made particularly for the organizations of Pakistan. It has been analyzed that which type of fringe benefits among the three (recreation leaves, health protection benefits and flexible working hours) appears the most important and should be made the part of employee compensation plan in order to retain the employees in the long run.

After successfully conducting this research and going through all the result finding of the 
study, it can be concluded that:

a) Recreation leaves appears the most important type of fringe benefit when it comes to level of satisfaction of employees. It have a highly positive impact on employee satisfaction, so it is recommended that recreation leaves must be pursued and offered in the kind of Casual leave, Sick leave, Annual Leave or Maternity leave. The more employees have paid time off, the more they are relaxed and less-distracted to their personal responsibilities over their professional lives.

b) Secondly, Health protection benefits are also an important fringe benefit and bring high level of satisfaction in the employees, and it is observed to be an important and preferred incentive that an employer can offer. Hence, the companies and organizations must adopt the policies and programs that support and encourage the fact that health protection benefit must be provided to the employees. It helps in retaining high potential employees.

c) Thirdly, Flexible Working Hours has a slighter impact on satisfaction of employees as compared to other fringe benefits since it helps them arrange their work in easy main lenient schedule without compromising on the output. Firms and organizations may adopt a policy about flexible working arrangements so that the employees are willing to work for a long time devotedly.

d) Through this study, it has been analyzed that a relationship exists between non monetary benefits and employee job satisfaction. Fringe benefits either they be of non monetary in nature, possess a great impact on employees and their satisfaction level.

Since this study is carried out to ascertain the relationship that exist between fringe benefits on employees morale and productivity, it implies that its findings would be of valued benefit to national and multinational companies in Pakistan, the individual staff, government and the society at large as it will give them a vivid insight into the pros, and cons of increasing productivity through fringe benefits implementation.

This study is much valued for the Human Resource professionals and employers in Pakistani firms and it will help them to design such compensatory packages that would provide a huge benefit to the firm and help them retain valuable employees.

\section{Conclusion}

Human Resource practices have been enhanced in many ways; the practices that are pursued today in human resources were never considered in the past. However, the employers today are in continuous search of loyal and dedicated employees, who can work and participate in betterment of the organization, this study analysis the relationship of Fringe Benefits and Employee Job Satisfaction, along with its key dimensions, Health Protection Benefits, Overtime, Recreation Leaves, and Flexible Working Hours. The results and interpretation of this research shows and confirms that a relationship exists between fringe and employees' job satisfaction. Employees who are provided the fringe benefits are more likely to last in an organization for a long time. However, employees expect more fringe benefits offerings to compensate their work with benefits and rewards. Providing Fringe benefits proved to be a vital and important policy for the organization since the employees have flexible schedule of 
work, health protection plans, recreation leaves such as annual leave, sick leave and maternity leave, and overtime facility. Fringe benefits are essential for any company because it directly and positively affects the employee satisfaction, the more employee is satisfies with his work and offerings, the more they tend to be loyal, dedicated, compassionate and profitable for the firm

Hence in a nutshell, this study found a strong connection between fringe benefits and how they relate with employee job satisfaction. More specifically, health protection benefits have positive but weak impact on employee satisfaction; however, it could be an important incentive that an employer can offer. Hence, companies and organizations must adopt the policies and programs that support and encourage the fact that health protection benefit must be provided to the employees. It helps in retaining high potential employees.

A strong positive impact has been observed of recreation leaves on employees' job satisfaction and it is suggested that recreation leaves must be offered in the forms of casual leaves, sick leaves, and annual leaves, paternal or maternity leaves. The more employees have paid time off, the more they are relaxed and less-distracted to their personal responsibilities over their professional lives.

And finally, flexible Working Hours brings a great deal of satisfaction to employees because it helps them arrange their work in an easy main lenient schedule without compromising on the output. Firms and organizations should always have a policy about flexible working arrangements so that the employees are willing to work for a long time devotedly.

\section{Acknowledgement}

First of all thank to ALLAH who is most merciful and kind to all of his creations without any discrimination and who make us able to prepare this research report.

We are generously grateful to my educator, Sir Dr. Danish, whose consolation, direction and support from the underlying to the last level empowered me to build up an understanding of the methodology of conducting research.

My thesis work has benefited from the wise counsel of many colleagues, teachers, employees and more numerous than I can fully acknowledge here. I would like to acknowledge those who participated in the occasions that we interacted to get formal feedback on our research that "what is the role of fringe benefits on employee satisfaction?"

In conclusion, I offer my respects and endowments to those who upheld me in any regard amid the fulfillment of my thesis.

\section{References}

Ali, A., Hussain, K. I., Ch, M. A., \& Akram, Ch, A. S. (2018). Level of Job Satisfaction among Employees of Banking Industries at Lahore 2016. European Online Journal of Natural and Social Sciences: Proceedings, 7(3(s)), pp-92. 
Casper, W. J., Harris, C., Taylor-Bianco, A., \& Wayne, J. H. (2011). Work-family conflict, perceived supervisor support and organizational commitment among Brazilian professionals. Journal of Vocational Behavior, 79(3), 640-652.

Chukwudumebi, C. S., \& Kifordu, A. A. (2018). The Significance of Fringe Benefits on Employee Morale and Productivity. Romanian Economic Journal, 21(68), 78-92.

Fronstin, P. (2013). Findings from the 2013 EBRI/Greenwald \& associates consumer engagement in health care survey. EBRI Issue Brief, (393).

Gupta, M. A. J. F. M., \& MANAGEMENT M. IMPACT OF FINANCIAL REWARDS ON EMPLOYEE'S SATISFACTION AND MOTIVATION, 81.

Jansen, N. W., Mohren, D. C., van Amelsvoort, L. G., Janssen, N., \& Kant, I. (2010). Changes in working time arrangements over time as a consequence of work-family conflict. Chronobiology international, 27(5), 1045-1061.

Kamau, H. N. (2013). Fringe benefits effects on employee productivity in the public sector (a case of state department of water, Nairobi County, Kenya), Doctoral dissertation, Doctoral dissertation, Kenyatta University.

King, R. B., Karuntzos, G., Casper, L. M., Moen, P., Davis, K. D., Berkman, L., ... \& Kossek, E. E. (2012). Work-family balance issues and work-leave policies. In Handbook of occupational health and wellness (pp. 323-339). Springer, Boston, MA.

Naithani, D. (2009). Overview of work-life balance discourse and its relevance in current economic scenario.

Odunlade, R. O. (2012). Managing employee compensation and benefits for job satisfaction in libraries and information centres in Nigeria.

Raja, U., Sheikh, R. A., Abbas, M., \& Bouckenooghe, D. (2018). Do procedures really matter when rewards are more important? A Pakistani perspective on the effects of distributive and procedural justice on employee behaviors. Revue Européenne de Psychologie Appliquée, 68(2), 79-88.

Schuler, R. S., \& Jackson, S. E. (1987). Linking competitive strategies with human resource management practices. Academy of Management Perspectives, 1(3), 207-219.

Sharma, K., \& Jaiswal, N. (2018). A Study on Employees Attitude towards Fringe Benefits. International Journal of Engineering and Management Research (IJEMR), 8(2), 176-180.

Sierpińska, M., \& Kulisa, B. (2018). Directions of Change in Corporate Fringe Benefits. Finanse, Rynki Finansowe, Ubezpieczenia, (1 (91) Zarządzanie finansami), 219-229.

Sirma, J. (2015). The Relationship between Work Life Balance Practices and Employee Performance: Case Study of UN Women Esaro (Doctoral dissertation, United States International University-Africa). 
Steyn, A. (2010). A comparative study to determine the impact of fringe benefits on job satisfaction and engagement (Doctoral dissertation, North-West University, Potchefstroom Campus).

\section{Copyright Disclaimer}

Copyright for this article is retained by the author(s), with first publication rights granted to the journal.

This is an open-access article distributed under the terms and conditions of the Creative Commons Attribution license (http://creativecommons.org/licenses/by/4.0/). 